\title{
Diet selection by Spanish ibex in early summer in Sierra Nevada
}

\author{
Teodora MARTÍNEZ
}

\begin{abstract}
Martínez T. 2000. Diet selection by Spanish ibex in early summer in Sierra Nevada. Acta Theriologica 45: 335-346.

Feeding strategy of the Spanish ibex Capra pyrenaica Schinz, 1838 was compared in two altitudinal zones of the Sierra Nevada, the high zone between 2700 and $3300 \mathrm{~m}$ a.s.l. and the mid-altitude zone between 2000 and $2700 \mathrm{~m}$ a.s.l. The study was carried out in July, and primarily focused on diet selection. Food availability, diet composition, species selection indices, and the effect of plant availability and chemical composition on diet selection in each zone were analysed. In the high zone, the availability of herbaceous resources was much greater than that of woody species, while in the mid-altitude zone, both resource types were almost equally abundant. Resource availability in both zones had a $36 \%$ index of similarity. Herbaceous plants were the predominant dietary component in both zones, and diet similarity was $51 \%$. The greater similarity found between the two diet compositions than between the two resource availabilities revealed preferences for common species in both zones. The Spanish ibex selected food items with moderate levels in diet composition, a degree of quality (high protein content and digestibility) and moderate availability. In the high zone, the ibex selected its diet according to the protein content, while in the mid-altitude zone the food choice was mainly influenced by availability. Spatial heterogeneity probably influenced the difference detected in terms of the feeding strategy used in each area.

Instituto Madrileño de Investigación Agraria (IMIA), Apdo 127, 28800 Alcalá de Henares, Madrid, Spain, e-mail: enctmm@encin.alcala.es

Key words: Capra pyrenaica, plant availability, diet, chemical parameters, feeding strategy
\end{abstract}

\section{Introduction}

Previous analyses of the Spanish ibex Capra pyrenaica Schinz, 1838 feeding habits have revealed variations between locations, seasons and sexes (Martínez 1988, 1989a, 1990, 1992, 1994, 1997, Martínez et al. 1985), indicating that the diet selection is influenced by a range of factors. However, these species choice processes are very little-known. Westoby (1978) and Belovsky (1985) found that herbivores adopt feeding strategies that maximise the ingestion of digestible energy and essential nutrients. Other authors such as Maizeret (1988) suggest that diet diversification is one of the fundaments of feeding behaviour.

According to Guillingham and Bunnell (1989), knowledge of the types and quantity of consumed food is an important aspect for understanding the natural history of animals, but a list of diet components reveals little about the selection processes. Analyses of the Spanish ibex diet composition in Sierra Nevada (Martínez 
$1988,1989 \mathrm{~b}, 1990$ ) have served as a basis for understanding the species' feeding habits during the summer period (July and August) in areas above $2000 \mathrm{~m}$ a.s.l. However, recognising that a wide range of factors is involved in a herbivore's diet selection (feed availability, plant chemical composition, digestibility, palatability, physiological state of the animal, digestive capacity and efficiency), this paper investigates some of the mechanisms used by the Spanish ibex to choose its food. For this purpose, parameters such as plant resource availability and chemical composition were analysed in the study area.

In the Sierra Nevada, the Spanish ibex is one of the most important fauna species. In this habitat, both animal and plant communities are extremely vulnerable due to adverse environment conditions throughout the year, and vegetation and animal species are intimately linked through the feeding process. Consequently, it is important to determine the feeding strategy used by the Spanish ibex populations in this type of habitat. The study, which focuses on the high and mid-altitude zones of the study area, seeks to understand and compare the Spanish ibex feeding strategy at the start of the summer in the two zones. The diet selection is analysed on the basis of the availability and chemical composition of the plant species.

\section{Study area}

The study area was located in Sierra Nevada (south-eastern Spain). Two zones defined in terms of altitude (the factor influencing the climate and consequently the vegetation) were analysed. The high zone, covering the highest parts of the mountain (a key habitat for the Spanish ibex in summer), was on the S side of the Sierra between 2700 and $3000 \mathrm{~m}$ a.s.l. The mid-altitude zone was on the N-NW side between 2000 and $2700 \mathrm{~m}$ a.s.l. Geologically, the area has a central nucleus of Palaeozoic origin formed by acidic rock which reaches the highest elevations. It is surrounded by a Mesozoic belt of Dolomite, limestone, and marble, which only extrudes at the W-NW end (Rodríguez de la Zubia 1969). The area is snow-covered for 8 to 9 months of the year, with a mean annual precipitation (10-year average) of 694 $\mathrm{mm}$ and a mean temperature of $4.7^{\circ} \mathrm{C}$ (Prieto 1983).

On the basis of Valle (1985), the study area is represented by two vegetation series: The Genisto baeticae-Juniperetum nanae sigmetum series is widely distributed between 2000 and $2800 \mathrm{~m}$ and is defined by several plant communities. Broom-juniper fields which previously had Juniperus communis, J. sabina and Pinus silvestris as abundant species, but currently this type of vegetation is heavily degraded and has been replaced by thorny-padded chamaephytes. Thyme-pasture includes communities of Thymus sephylloides, and also herbaceous species such as Agrostis nevadensis and Ameria filicaulis. Wet meadows include communities formed by A. nevadensis and Herniaria boissieri, which mark the transition to other hygrophyllous communities with Nardus stricta and Festuca iberica.

The second series: Erigeronto frigidi-Festucetum clementei sigmetum, lies above $2700 \mathrm{~m}$ a.s.l. Its communities include pastures which are subject to strong winds, snow during most of the year and summer drought, typical species include Festuca clementei, $F$. pseudeskia and A. nevadensis, wet meadows formed by the communities defined in the above series and by characteristic species such as Armeria splendens, and rocky outcrops which tend to be colonised by low pioneer species.

\section{Material and methods}

Several methods and techniques were used due to the large number of parameters analysed. These are described in detail in Martínez (1992). A résumé is given here. 
The vegetation was sampled systematically in the two zones, using sampling transects and plots set in different types of vegetation in accordance with the altitudinal gradient and its heterogeneity, Following Walker (1976) with certain modifications, the floristic composition of the herbaceous and woody strata were evaluated independently. Data from the two strata and the area covered by each type of vegetation (1:50 000 map of crops and land uses in Guedar-Sierra) were used to estimate the biomass contribution by each vegetation species in proportion to the total vegetation.

The botanical composition of the herbaceous stratum was evaluated using the ranking method (Mannetje and Haydock 1963) to calculate the specific constants for each study area. The sampling transects measured $500 \mathrm{~m}$ by $1 \mathrm{~m}$, with $1 \mathrm{~m}^{2}$ sampling units set every $20 \mathrm{~m}$ along the line. The biomass of the shrub species was evaluated on the basis of their volume, and linked to weight using regression equations. A series of $10 \mathrm{~m}^{2}$ sub-plots were set every $25 \mathrm{~m}$ along each $189 \times 5 \mathrm{~m}$ sampling plot. The height and largest and smallest diameters of all plants found were measured in each sub-plot. The volume was subsequently estimated on the basis of these parameters.

The Spanish ibex diet was studied using fecal analysis. The technique described by Cavender and Hansen (1970) was employed with minor modifications in both the physical and chemical treatments, which facilitated identification and quantification of species, as described in Martínez (1988). Twenty-five samples collected from each zone in July (taken directly from groups of previously located indiriduals) were analysed.

The degree of overlap between the diets was estimated using Kulczynski's Similarity Index (Oosting 1956), KSI $=[\Sigma 2 \mathrm{~W} / \Sigma(\mathrm{a}+\mathrm{b})] \times 100$, where $\mathrm{W}$ is the lesser percentage of a common component in the two diets to be compared and $(a+b)$ is the sum of percentages of components of the two diets being compared. The similarity between food availability in two zones was also estimated using KSI. The diversity of plant species in the diets and availability was estimated according to the Shaרnon-Weaver Index (Pielou 1975), $H^{\prime}=-\Sigma p_{i} \log _{10} p_{i}$, where $p_{i}$ is the proportion of the total diet or availability belonging to the ith species.

Both diet composition and resource availability were analysed by species, by trophic or plant groups: shrubs, chamaephytes, graminoids (grasses, sedges and rushes) and forbs (total herbaceous excepting for grasses, sedges and rushes), and also by woody and herbaceous plants. Particular plant species were evaluated on the basis of the corresponding chemical analyses. Protein content (PROT) was estimated using the Kjeldahl method with an Kjeldahl Bouat-Afora air-dragging device. Other parımeters: cellular content (CC), neutral-detergent fibre (NDF), acid-detergent fibre (ADF), hemicellulose (HEM), cellulose (CE), lignin (LIG), and aparent digestibility of dry matter (DDM) were determined by the method of Goering and Van Soest (1970) with modifications suggested by Garía-Criado (1974). The selection of plant species was estimated by the Ivlev's Selectivity Index, ISI $=(\mathrm{D}-\mathrm{A}) /(\mathrm{D}+\mathrm{A})$, where $\mathrm{D}-\operatorname{diet}$ (consumption) and $\mathrm{A}-$ availability.

The influence of different factors or variables on diet selection by the Spanish ibex in both zones was determined on the basis of three statistical approaches: Spearman's Correlation Rank Coefficient $\left(r_{\mathrm{S}}\right)$, Multiple Step-wise Regression $\left(R^{2}\right)$ and Principal Components Analysis (PCA). Spanish ibex diet (SID) was the dependent variable, while the independent variables were: plant availability (A) and the parameters of the chemical composition of the previously defined plants. In the PCA, the variables were: Spanish ibex diet, plant availability and chemical composition parameters of plant species.

\section{Results}

\section{Herbaceous and shrub strata}

In the high zone herbaceous stratum, 68 species with an estimated biomass of $1497 \mathrm{~kg} /$ ha were evaluated. The diversity was $1.28 \mathrm{bits}$. The graminoid group was the most abundant, representing $69 \%$ of the total biomass and having diversity of 1.0 bits. The forbs represented the remaining biomass $(31 \%)$ and their diversity was 1.2 bits. In the mid-altitude zone, 52 species with an estimated biomass of $34<2 \mathrm{~kg} /$ ha were recorded. The diversity was 1.05 bits. The graminoid group 
comprised $85.9 \%$ of the total biomass and its diversity was 0.97 bits. Forbs comprised the rest of biomass (14.1\%), with a diversity of 0.95 bits.

In the high zone, the shrub stratum only covers a small zone in the study area and is very little developed, being restricted to diverse chamaephyte species and a few low prostrate shrubs which reflect the harsh, adverse climatic conditions. Seven species were found, the estimated volume was $422.9 \mathrm{~m}^{3} / \mathrm{h}$ a and the estimated biomass was $4191.6 \mathrm{~kg} / \mathrm{ha}$. The density was 25000 plants/ha and the species diversity was 0.42 bits. Six woody species were evaluated in the mid-altitude zone, with a plant density of 50000 individuals/ha. The estimated volume was 1406.6 $\mathrm{m}^{3} /$ ha of shrub matter and dry weight biomass of $14963.3 \mathrm{~kg} / \mathrm{ha}$. The diversity was 0.41 bits.

\section{Floristic composition and total plants availability}

Table 1 shows the most abundant species in the study area (percentages $\geq 0.5 \%$ ). In the high zone, the herbaceous vegetation formed the largest part of the plant biomass $(87 \%)$. In contrast, the biomass contributed by the woody vegetation (shrubs-chamaephytes) constituted 13\%. In the biomass of each trophic group, graminoids were the most abundant, followed by forbs, shrubs and chamaephytes (Fig. 1).

The species composition of the mid-altitude zone is summarised in Table 1. Herbaceous plants comprised $57.3 \%$ of the total biomass and woody plants comprised the remaining (42.7\%). Figure 1 shows biomass separated into trophic groups. The most abundant group was graminoids, followed closely by shrubs, then forbs and finally chamaephytes, which were not abundant.

Quantitative and qualitative differences were found between the availability of food resources of the two zones (Table 1). These differences are reflected in the low similarity index between respective food supplies (36\%). The similarity indices amongst the corresponding plant groups did not exceed 50\%, except amongst the chamaephytes $(57.9 \%)$ which was the highest. The group of graminoids had a mid-range similarity index $(49.5 \%)$, while those of shrubs and forbs were quite low $(28.5 \%)$. In both zones, herbaceous vegetation contributed more biomass than woody vegetation, although the latter was considerably more abundant in the mid-altitude zone. The estimated biomass per hectare in the two zones differed considerably. Herbaceous vegetation biomass/ha in the mid-altitude zone was double that of the high zone, and woody vegetation biomass/ha was four times higher. Influential factors were vegetation density, form of growth, and type of species found in each zone. The diversity index and species richness were greater in the high zone.

\section{Spanish ibex diet}

The Spanish ibex diet in the mid- and high-altitude zones was described by Martínez (1988, 1990). For illustrative purposes, however, Table 1 summarises the diet composition in each zone, and Fig. 1 shows the importance of each plant group. Essentially, 39 plant species were identified in the upper zone, with a diversity of 
Table 1. Resource availability (A), Spanish ibex diet (D) and species selection (ISI) in the high and mid-altitude zones of Sierra Nevada.

\begin{tabular}{|c|c|c|c|c|c|c|}
\hline \multirow{3}{*}{ Plant species } & \multicolumn{6}{|c|}{ Biomass (\%) } \\
\hline & \multicolumn{3}{|c|}{ High zone } & \multicolumn{3}{|c|}{ Mid-altitude zone } \\
\hline & A & $\mathrm{D}$ & ISI & A & $\mathrm{D}$ & ISI \\
\hline 1 & 2 & 3 & 4 & 5 & 6 & 7 \\
\hline \multicolumn{7}{|l|}{ Shrubs } \\
\hline Cytisus purgan & 7.9 & 1.0 & -0.75 & - & - & - \\
\hline Juniperus nana & 2.5 & 5.5 & 0.37 & 10.4 & 4.0 & -0.45 \\
\hline J. sabina & 0.4 & 4.0 & 0.80 & 2.0 & 3.0 & 0.20 \\
\hline Genista baetica & - & - & - & 28.7 & 3.5 & -0.78 \\
\hline Pinus sylvestris & - & - & - & - & 5.7 & - \\
\hline \multicolumn{7}{|l|}{ Chamaephytes } \\
\hline Thymus serpylloides & 1.4 & 1.1 & -0.12 & 1.0 & 0.3 & -0.50 \\
\hline Sideritis glacialis & 0.4 & 0.4 & 0 & - & - & - \\
\hline Ptilotrichum spinosum & 0.2 & 3.0 & 0.88 & 0.1 & 1.2 & 0.85 \\
\hline Reseda complicata & - & 1.8 & - & - & - & - \\
\hline Helianthemum sp. & - & - & - & 0.5 & 1.0 & 0.33 \\
\hline Others & 0.2 & 0.2 & - & - & - & - \\
\hline \multicolumn{7}{|l|}{ Graminoids } \\
\hline Festuca pseudeskia & 13.3 & 1.0 & -0.86 & 2.4 & - & - \\
\hline Agrostis nevadensis & 11.4 & 16.0 & 0.17 & 9.7 & 16.6 & 0.26 \\
\hline Nardus stricta & 5.5 & 10.0 & 0.29 & 2.3 & - & - \\
\hline Festuca clementei & 5.0 & 5.3 & 0.03 & - & - & - \\
\hline F. iberica & 3.5 & 9.5 & 0.46 & 2.9 & 14.5 & 0.65 \\
\hline Carex nevadensis & 2.7 & 3.0 & 0.05 & - & - & - \\
\hline Koeleria caudata & 2.7 & - & - & 0.5 & 3.3 & 0.74 \\
\hline Festuca nevadensis & 2.6 & - & - & 1.8 & 3.0 & 0.25 \\
\hline Dactylis glomerata & 2.3 & 7.7 & 0.54 & 2.2 & 6.9 & 0.52 \\
\hline Festuca ovina & 1.4 & 3.7 & 0.45 & 1.8 & 6.5 & 0.57 \\
\hline Deschampsia flexuosa & 1.3 & 1.6 & 0.10 & 5.1 & 8.6 & 0.25 \\
\hline Holcus caespitosus & 1.3 & 0.2 & -0.73 & - & - & - \\
\hline Carex nigra & 1.1 & 1.2 & 0.04 & - & - & - \\
\hline Poa alpina & 1.0 & - & - & - & - & - \\
\hline Festuca frigida & 0.5 & 2.7 & 0.68 & - & - & - \\
\hline Trisetum glaciale & 0.5 & 1.6 & 0.52 & - & - & - \\
\hline Festuca indigesta & - & 0.5 & - & 12.1 & 3.2 & -0.57 \\
\hline Anthoxantum odoratum & 0.5 & 1.3 & 0.42 & 0.2 & 0.6 & 0.50 \\
\hline Luzula spicata & - & 0.8 & 0.45 & - & - & - \\
\hline Festuca scariosa & - & - & - & 5.0 & 3.3 & -0.20 \\
\hline F. rivularis & - & - & - & 0.5 & 0.6 & 0.09 \\
\hline Arrhenatherum elatius & - & - & - & 0.8 & 1.8 & 0.38 \\
\hline Carex sp. & - & - & - & - & 1.2 & - \\
\hline Luzula sp. & - & - & - & - & 0.6 & 0.50 \\
\hline Trisetum sp. & - & - & - & - & 0.6 & 0.50 \\
\hline Others & 2.9 & 1.5 & - & 2.0 & 2.0 & - \\
\hline
\end{tabular}


Table 1 - concluded.

\begin{tabular}{|c|c|c|c|c|c|c|}
\hline 1 & 2 & 3 & 4 & 5 & 6 & 7 \\
\hline \multicolumn{7}{|l|}{ Forbs } \\
\hline Arenaria tetraquetra & 7.6 & 1.1 & -0.75 & 1.2 & 0.6 & -0.33 \\
\hline Lotus glareosus & 2.8 & 1.2 & -0.53 & 0.1 & 0.5 & 0.42 \\
\hline Senecio pyrenaicus & 2.2 & 0.5 & -0.64 & - & - & - \\
\hline Leontodon microcephalus & 1.7 & 0.3 & -0.70 & - & - & - \\
\hline Plantago alpina & 1.6 & - & - & 1.1 & - & - \\
\hline Crepis oporinoides & 1.5 & 1.0 & -0.20 & - & - & - \\
\hline Leontodon boryi & 1.3 & - & - & - & - & - \\
\hline Reseda complicata & 1.4 & 1.8 & 0.13 & - & - & - \\
\hline Sempervivum nevadense & 1.0 & - & - & 1.3 & - & - \\
\hline Plantago nivalis & 0.9 & - & - & - & - & - \\
\hline Jasione crispa & 0.9 & - & - & - & - & - \\
\hline Herniaria boissieri & 0.6 & - & - & - & 0.5 & - \\
\hline Eryngium glaciale & 0.5 & 1.8 & 0.56 & 0.7 & - & - \\
\hline Ranunculus demissus & 0.4 & 0.6 & 0.20 & - & - & - \\
\hline$R$. acetosellifolius & 0.4 & 2.5 & 0.78 & - & - & - \\
\hline Anthyllis vulneraria & 0.1 & 1.3 & 0.73 & - & - & - \\
\hline Rumex acetosella & 0.1 & 0.5 & 0.66 & 0.1 & 1.3 & 0.70 \\
\hline Silene boryi & 0.1 & 0.1 & 0.00 & 0.2 & 0.6 & 0.50 \\
\hline Cardus sp. & - & - & - & 0.7 & - & - \\
\hline Dianthus sp. & - & - & - & 0.6 & - & - \\
\hline Hieracium pilosella & - & - & - & 0.2 & 0.8 & 0.60 \\
\hline Others & 1.7 & 2.7 & - & 2.8 & 3.8 & - \\
\hline Sphagnum sp. & 0.7 & - & - & - & - & - \\
\hline
\end{tabular}

Available

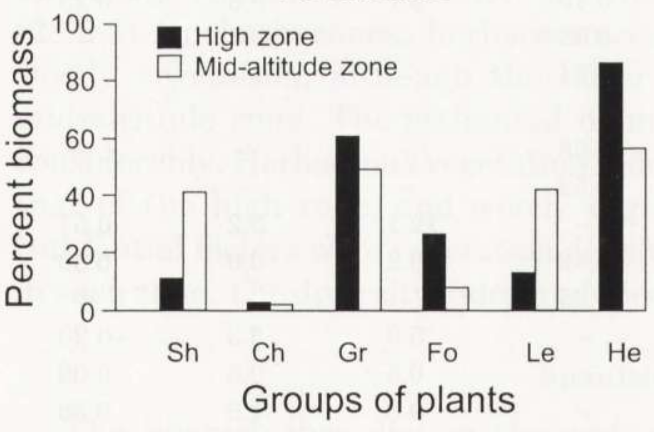

Consumed

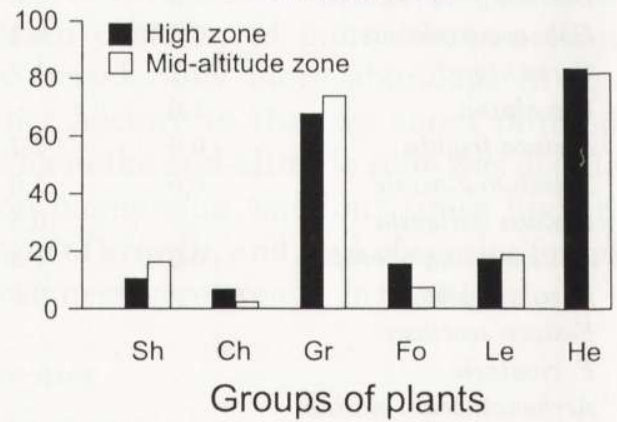

Fig. 1. Groups of plants available and consumed by Spanish ibex in high and mid-altitude zones of Sierra Nevada. Sh - shrubs, Ch - chamaephytes, Gr - graminoids, Fo - forbs, Le - ligneous plants, He herbaceous plants. 
1.13 bits. The most heavily consumed plant group was the graminoids, followed by forbs and shrubs, while the chamaephytes were the least used group. In the mid-altitude zone, 34 species were identified with a diversity of 1.19 bits. The trophic group contributing most to the Spanish ibex diet was the graminoids, followed by trees and shrubs, then forbs and finally chamaephytes.

The similarity between the ibex diet in two zones was $51.1 \%$. It was low amongst the forbs group (23.6\%) and amongst the chamaephytes (33.3\%). However, it was higher amongst the shrubs $(52.4 \%)$, and particularly amongst the graminoids $(57 \%)$. The chamaephyte and forb groups were consumed twice as much in the high as in the mid-altitude zone. In contrast, the consumption level of the most important group (graminoids) in the diet of both zones was similar, with no significant difference to the consumption of trophic groups $\left(\chi^{2}=6, \mathrm{df}=3, p>0.05\right)$ or to woody and herbaceous plants consumed in the two zones $\left(\chi^{2}=0.1, \mathrm{df}=1\right.$, $p>0.05)$. The diet diversity was greater in the high than the mid-altitude zone.

\section{Food chemical composition}

Table 2 lists several chemical components of various plant species available to and consumed by the Spanish ibex in the two study zones. Agrostis nevadensis had a high protein content and digestibility. Other species with relatively high protein or digestibility values were Festuca clementei, Carex sp., Anthoxantum odoratum, Eryngium glaciale, Festuca iberica, Nardus stricta, Dactylis glomerata and Senecio pyrenaicus. Another important chemical component in the plants, which may influence herbivore dietary selection, is lignin content. Woody plants had the highest content, especially Juniperus sabina and Cytisus purgans, while in herbaceous plents this component ranged between $5.8 \%$ and $1.7 \%$, corresponding respectively to Festuca pseudeskia, a little consumed item, and A. nevadensis, a heavily consumed iten.

\section{Plants species selected by the Spanish ibex}

Table 1 shows the Ivlev's Selectivity Indices for plant species consumed by the Spanish ibex in the high and mid-altitude zones. Amongst the woody plants in the high zone, the plant species with the highest indices were not abundant, but were relatively important in the diet; this was the case with Juniperus sabina and Ptilotrichum spinosum. The graminoids group had the largest number of positively selected species, although species with the highest indices were not particularly abindant. In contrast, species such as $F$. pseudeskia, an abundant resource in the zone, had an extremely negative index. This plant, unpalatable due to its spiny leaves, was very little consumed. The forbs included species with extremely high and extremely low indices, the latter corresponding to relatively abundant resources and low consumption.

In the mid-altitude zone, shrub plants were avoided, except for J. sabina. In contrast, the group of chamaephytes was preferred, except for Thymus serpylloides. 
Table 2. Chemical composition of plant species important in availability and in Spanish ibex diet in Sierra Nevada. PROT - protein, CC - cellular content, NDF - neutral-detergent fibre, ADF - acid-detergent fibre, HEM - hemicellulose, CE - cellulose, LIG - lignin, DDM - apparent digestibility of dry matter.

\begin{tabular}{|c|c|c|c|c|c|c|c|c|}
\hline \multirow{2}{*}{ Plant species } & \multicolumn{8}{|c|}{ Components (\%) } \\
\hline & PROT & $\mathrm{CC}$ & NDF & $\mathrm{ADF}$ & HEM & $\mathrm{CE}$ & LIG & DDM \\
\hline \multicolumn{9}{|c|}{ Woody plants } \\
\hline Cytisus purgans & 10.4 & 57.4 & 42.6 & 48.8 & 8.6 & 19.7 & 29.1 & 40.7 \\
\hline Sideritis glacialis & 9.5 & 43.0 & 57.0 & 38.5 & 4.5 & 12.5 & 26.0 & 55.1 \\
\hline Juniperus sabina & 7.5 & 29.9 & 70.2 & 40.8 & 10.9 & 21.7 & 19.1 & 59.2 \\
\hline Juniperus nana & 7.1 & 37.9 & 62.1 & 36.1 & 1.9 & 12.2 & 23.9 & 58.1 \\
\hline \multicolumn{9}{|c|}{ Herbaceous plants } \\
\hline Agrostis nevadensis & 24.0 & 41.1 & 58.9 & 23.0 & 18.1 & 1.7 & 21.3 & 77.4 \\
\hline Festuca clementei & 15.9 & 62.9 & 37.1 & 37.5 & 25.4 & 4.9 & 32.6 & 60.5 \\
\hline Carex nigra & 14.3 & 56.5 & 43.5 & 32.4 & 24.2 & 5.1 & 27.6 & 59.6 \\
\hline Anthoxanthum odoratum & 14.2 & 51.6 & 48.4 & 29.2 & 22.4 & 2.7 & 26.5 & 71.2 \\
\hline Festuca iberica & 12.6 & 58.7 & 41.4 & 34.1 & 24.5 & 3.9 & 30.3 & 65.2 \\
\hline Nardus stricta & 12.5 & 57.2 & 42.8 & 29.2 & 28.1 & 2.6 & 26.6 & 70.4 \\
\hline Dactylis glomerata & 12.3 & 54.3 & 45.7 & 30.8 & 23.5 & 3.0 & 27.8 & 69.5 \\
\hline Festuca nevadensis & 11.6 & 52.4 & 47.6 & 31.9 & 20.5 & 2.7 & 29.2 & 72.6 \\
\hline Deschampsia flexuosa & 10.6 & 62.4 & 37.6 & 43.4 & 19.1 & 5.0 & 38.3 & 63.5 \\
\hline Festuca ovina & 10.5 & 71.5 & 28.6 & 45.0 & 26.5 & 3.5 & 41.5 & 70.3 \\
\hline Koeleria caudata & 9.8 & 60.5 & 39.5 & 36.4 & 24.1 & 3.4 & 33.0 & 67.0 \\
\hline Festuca indigesta & 9.1 & 57.8 & 42.2 & 31.9 & 25.9 & 3.4 & 28.5 & 66.9 \\
\hline Festuca pseudeskia & 7.3 & 69.5 & 30.5 & 42.5 & 27.1 & 7.1 & 35.4 & 52.4 \\
\hline Eryngium glaciale & 13.3 & 33.2 & 66.8 & 30.9 & 2.3 & 5.3 & 25.6 & 69.2 \\
\hline Senecio pyrenaicus & 12.2 & 20.9 & 79.1 & 20.5 & 0.4 & 3.2 & 17.3 & 75.7 \\
\hline Rumex acetosella & 10.5 & 30.4 & 69.7 & 26.1 & 4.3 & 5.8 & 20.4 & 67.9 \\
\hline
\end{tabular}

Almost all species forming the graminoids group were preferred, except for Festuca scariosa, and $F$. indigesta which was consumed very little although it is quite abundant in the zone.

The selection indices of consumed species revealed that the Spanish ibex generally followed a similar species selection pattern in the two zones. The grass species with a high protein content or digestibility were positively selected in both zones. The most abundant forb species were avoided. The highest quality woody plants were preferred, except for the most abundant items. Amongst the trophic groups, the chamaephytes and graminoids were preferred in both zones, while shrubs and forbs were avoided.

\section{Influence of availability and chemical composition on food on diet selection}

The selection of the herbaceous component of the diet was analysed after finding that herbaceous vegetation formed the majority of the Spanish ibex diet in both the 
high and mid-altitude zones ( $83 \%$ and $81.3 \%$, respectively). In the mid-altitude zone, only the selection of the herbaceous component could be analysed, as chemical parameters of Pinus silvestris and Genista baetica, and availability of $P$. silvestris were not available.

In the high zone, the herbaceous component of the Spanish ibex diet correlates with its protein content $\left(r_{\mathrm{S}}=0.54, n=19, p<0,05\right)$. No correlation was observed with any other parameter. The regression analysis revealed that the herbaceous component of the diet was influenced by the protein content, the only variable entering in the configuration of the model $\left(R^{2}=0.48, F=12.3, p<0.01\right)$. The Principal Components Analysis (PCA) (Table 3), also revealed important information. The herbaceous component of the diet and the protein content of the rescurces had positive scores on Component II. The lignin content had positive scores on Component III, while digestibility had negative scores. In the mid-altitude zone, the herbaceous component of the diet correlated with its avalability $\left(r_{\mathrm{S}}=0.54, n=16, p<0.05\right)$. Stepwise regression analysis indicated that protein content is the only variable included in the model $\left(R^{2}=0.34, F=7.3, p<\right.$ 0.05 ). The PCA (Table 3), provides important information: diet and availability scored positively on Component II.

In the high zone, no correlation was found in the diet with either availability or the chemical composition parameters. According to the stepwise regression analysis, the protein content of the Spanish ibex food influences its diet selection $\left(R^{2}=0.37\right.$, $F=10.2, p<0.01$ ). The PCA (Table 3) provides similar results to those of the

Tabl 3. Principal Components Analysis (PCA). Loading factors of variables in the 3 principal axes. SID - Spanish ibex diet, A - availability, PROT- protein, NDF - neutral-detergent fibre, CC - cellular content, ADF - acid-detergent fibre, HEM - hemicellulose, LIG - lignin, CE - cellulose, DDM apprent digestibility of dry matter. Herbaceous component of $\operatorname{diet}$ (DHC) and total diet (TD). * - Ioad factors defined.

\begin{tabular}{|c|c|c|c|c|c|c|c|c|c|}
\hline \multirow{2}{*}{ Comonents } & \multicolumn{3}{|c|}{ High zone (DHC) } & \multicolumn{3}{|c|}{ Mid-altitude zone (DHC) } & \multicolumn{3}{|c|}{ High zone (TD) } \\
\hline & I & II & III & I & II & III & I & II & III \\
\hline SID & -0.05 & $0.44^{*}$ & 0.08 & 0.22 & $0.47^{*}$ & 0.29 & -0.08 & $0.42^{*}$ & 0.32 \\
\hline A & 0.06 & 0.25 & 0.50 & 0.11 & $0.39^{*}$ & 0.11 & -0.20 & 0.14 & 0.39 \\
\hline PROT & -0.19 & $0.36^{*}$ & 0.05 & 0.36 & 0.22 & -0.09 & -0.01 & $0.44^{*}$ & 0.05 \\
\hline NDF & -0.41 & 0.11 & -0.07 & -0.43 & 0.26 & -0.12 & -0.48 & -0.04 & -0.01 \\
\hline $\mathrm{CC}$ & -0.41 & -0.11 & 0.07 & 0.43 & -0.26 & 0.12 & 0.48 & 0.03 & 0.01 \\
\hline $\mathrm{ADF}$ & 0.39 & -0.06 & 0.03 & -0.28 & -0.28 & 0.55 & -0.28 & -0.35 & 0.23 \\
\hline HEN & 0.33 & 0.21 & -0.13 & -0.30 & 0.28 & -0.47 & -0.41 & 0.15 & -0.19 \\
\hline LIG & 0.14 & -0.28 & $0.55^{*}$ & -0.28 & -0.28 & 0.55 & 0.10 & -0.34 & $0.50^{*}$ \\
\hline $\mathrm{CE}$ & 0.39 & -0.00 & -0.09 & -0.40 & 0.25 & 0.09 & -0.43 & -0.12 & -0.19 \\
\hline DDN & -0.29 & 0.10 & $-0.50^{*}$ & 0.38 & 0.15 & -0.35 & 0.14 & 0.35 & $-0.44^{*}$ \\
\hline $\begin{array}{l}\% \text { of } x \text { xplained } \\
\text { varance }\end{array}$ & 41.7 & 33.0 & 10.6 & 46.3 & 24.4 & 13.8 & 34.9 & 31.8 & 15.6 \\
\hline
\end{tabular}


herbaceous component. Ibex diet and protein content of plants had positive scores on Component II. Component III groups lignin food content in the positive region and digestibility in the negative region. None of the analyses revealed any influence of availability in diet selection.

\section{Discussion}

Despite their relative proximity to each other, the two zones have several ecological differences. The altitudinal variable influences climatic conditions and causes variation in the vegetation composition and structure. This variation influenced the Spanish ibex diet and feeding strategy in the two zones.

\section{Diet composition}

The fact that the similarity index between the Spanish ibex diet in the two zones was moderate $(51 \%)$, underscores the quantitative and qualitative similarities and differences between the diets in the two zones. Amongst the differences, some resources were consumed in different percentages in one of the two zones, or were part of the diet in one zone and not the other. This may be due to several reasons: more palatable and preferred plants may grow in the zone where they are less heavily consumed, or are unavailable in the area where they are not consumed, as is the case with $F$. clementei and $F$. frigida in the mid-altitude zone, and $F$. indigesta, $P$. sylvestris and G. baetica in the high zone. The lower availability of one resource in one of the zones or its advanced phenological state (lower palatability) may influence its consumption. This was probably the case for Nardus stricta, consumed in the high zone but unconsumed in the mid-altitude zone.

Amongst the similarities, some of the most representative species of the study area were consumed in large proportions in both zones. This was the case for A. nevadensis, $F$. iberica, D. glomerata and $F$. ovina, some of which, such as A. nevadensis and $D$. glomerata had high selection indices. This suggests that the ibex has preferences for certain common trophic resources in both zones, and in fact the similarity between the diets was higher than between the food availabilities. It should be noted that almost the same amount of woody plants was consumed in both zones, although they were much more abundant in the mid-altitude zone. Unlike this study area, the woody plants in low zones of lower altitude areas, such as the Sierras de Beceite or Sierras de Cazorla (Mediterranean areas), are substantially more consumed than in the high zones (Martínez 1994, 1997). In Sierra Nevada, the Spanish ibex has a different feeding pattern: richer in grasses and similar to the mountain areas of the Sierra de Gredos (Martínez and Martínez 1987), which are more similar by climatic and edaphic conditions.

\section{Feeding strategy}

The Spanish ibex feeding strategy differs somewhat in the two zones, with certain common traits. According to Owen-Smith (1979), the feeding efficiency of 
large herbivores is affected by the state of their food resources. Similarly, Skogland (1980) claims that if the state of the vegetation changes, the width of trophic niche can undergo changes, along with the food intake. In the high zone, both the composition of the entire diet and its herbaceous component were influenced by resources quality. The ibex consumed the most protein-rich and digestible food, while the species with the highest cellulose and lignin content were consumed very little and not selected. In the mid-altitude zone, on the other hand, the selection of the herbaceous component of the Ibex diet was influenced by resource availability, although protein content was also important to some extent. Thus, the Spanish ibex consumed food that was protein-rich but also had a higher lignin content and a lower digestibility, as it ingested a larger amount of shrubs than in the high zone. The fact that the protein content of the food is reflected in the diet selection in both zones is important, as nitrogen plays a key role in all metabolic processes, especially in growth (Mattson 1980). It is also fundamental in reproductive mechanisms: the fertility of several ungulates correlates with plant nitrogen content (Crawley 1983).

The diet diversity and the number of species consumed were higher in the high zone than the mid-altitude zone (as was the case with resource availability), suggesting that the Spanish ibex tended towards a greater diet diversity in habitats where the species diversity was also greater. The greater trophic niche width, as with the influence of food quality, suggests a greater degree of diet selection in the high zone. However, although the Spanish ibex may use slightly different strategies in each zone, I conclude that in the Sierra Nevada, at altitudes above $2500 \mathrm{~m}$, the Spanish ibex has similar feeding habits in both zones and primarily selects its diet on the basis of quality (protein content). In both the upper and the mid-altitude zone, the Spanish ibex tries to optimise its use of the available resources (some of which have a high fibre and lignin content). In the high zone it has a more diverse and selective diet with a higher protein content and a lower shrub consumption; while in the mid-altitude zone it ingests a larger amount of shrubs, consuming the most abundant herbaceous resources and at the same time selecting those with the highest quality. By this means, it acquires the nutrients necessary to cover its needs, as the food intake changes in response to the prevailing state of the food resources (Skogland 1984).

Acknowledgments: I wish to express my gratitude to E. Martínez for her help in field sampling.

\section{References}

Belovsky G. E. 1985. A model of herbivore diet choice: Implications for mammlian herbivore diet selectivity and food competition. Abstracts of Fourth International Theriological Congress, no 54, Sección S25, Edmonton, Canada: 1-389.

Cavender B. R. and Hansen R. M. 1970. The microscopic method used for herbivore diet estimates and botanical analysis of litter and mulch at the Pawnee Site. IBP Technical Report, No 18. Natural Resources Ecology Laboratory. Colorado State University, Fort Collins, Colorado: 1-6.

Crawley M. J. 1983. Herbivory: The dynamics of animal-plant interactions. Studies in ecology. Volume 10. Blackwell Scientific Publications, Oxford: 1-435. 
Garcia-Criado B. 1974. Fraccionamiento químico de alimentos forrajeros y su evaluación por métodos de laboratorio. Separata de "Acta Salmanticensia", Serie de Ciencias 53. Facultad de Ciencias. Universidad de Salamanca: 1-75.

Goering H. K. and Van Soest P. J. 1970. Forage fiber analysis. Agricultural Handbook. United States Department of Agriculture. Research Service: 1-19.

Guillingham M. P. and Bunnell F. L. 1989. Effects of learning on food selection and searching behaviour of deer. Canadian Journal Zoology 67: 24-32.

Maizeret C. 1988. Stratégies alimentaires des chevreuils: les fondements écologiques d'une diversification du régime. Acta OEcologica, OEcologia Applicata 9: 192-221.

Mannetje L. and Haydock K. P. 1963. The dry-weight rank method for the botanical analysis of pasture. Journal of the British Grassland Society 18: 268-275.

Martínez T. 1988. Utilisation de l'analyse micrographique des fèces pour l'étude du régime alimentaire du bouquetin de la Sierra Nevada (Espagne). Mammalia 52: 465-473.

Martínez T. 1989a. Recursos tróficos de la cabra montés (Capra pyrenaica, Schinz, 1938) en la Sierra de Gredos, durante Otoño e Invierno. Ecología 3: 179-186.

Martínez T. 1989b. Comparison of the diet the Spanish Ibex (Capra pyrenaica) in three areas of Sierra Nevada, Spain. Abstracts of Fifth International Theriological Congress, Roma: 1-147.

Martínez T. 1990. Régimen alimentario de la cabra montés (Capra pyrenaica) en la zona alpina de Sierra Nevada durante los meses de Julio y Agosto. Ecología 4: 177-185.

Martínez T. 1992. Estrategia alimentaria de la cabra montés (Capra pyrenaica) y sus relaciones tróficas con los ungulados silvestres y domésticos en $\mathrm{S}^{\mathrm{a}}$ Nevada, $\mathrm{S}^{\mathrm{a}}$ de Gredos y $\mathrm{S}^{\mathrm{a}}$ de Cazorla. Facultad de Ciencias, Biológicas, Universidad Complutense de Madrid, Madrid: 1-521.

Martínez T. 1994. Hábitos alimentarios de la cabra montés (Capra pyrenaica) en zonas de distinta altitud de los puertos de Tortosa y Beceite. Referencia a la dieta de los machos y hembras. Doñana, Acta Vertebrata 21: 25-37.

Martínez T. 1997. Dieta estacional de la cabra montés (Capra pyrenaica, Schinz) en dos zonas de distinta altitud en la Sierra de Cazorla. Actas de la XXXVII Reunión Científica de la Sociedad Española para el Estudio de los Pastos: 433-440.

Martínez T. and Martínez E. 1987. Diet of Spanish wild goat, Capra pyrenaica, in spring and summer at the Sierra de Gredos, Spain. Mammalia 51: 548-557.

Martínez T., Martínez E. and Fandos P. 1985. Composition of the food of the Spanish wild goat in Sierras de Cazorla and Segura, Spain. Acta Theriologica 30: 461-494.

Mattson W. J. 1980. Herbivory in relation to plant nitrogen content. Annual Review of Ecology and Systematics 11: 119-161.

Oosting D. H. 1956. The study of plant communities. W. H. Freeman and Company, San Francisco: $1-440$.

Owen-Smith N. 1979. Assessing the foraging efficiency of a large herbivore, the kudu. South African Journal of Wildlife Research 9: 102-110.

Pielou E. C. 1975. Ecological diversity. Wiley Interscience, London: 1-384.

Prieto P. 1983. Flora de la Tundra de Sierra Nevada. Universidad de Granada. Granada, España: 1-236.

Rodríguez de la Zubia M. 1969. La cabra montés en Sierra Nevada. Ministerio de Agricultura, Madrid: $1-95$.

Skogland T. 1980. Comparative summer feeding strategies of Artic and Alpine Rangifer. Journal of Animal Ecology 49: 81-98.

Skogland T. 1984. Wild reindeer foraging-niche organization. Holartic Ecology 7: 345-379.

Valle F. 1985. Mapa de las series de vegetación de Sierra Nevada (España). Ecología Mediterránea 8: 183-189.

Walker B. H. 1976. An approach to the monitoring of changes in the composition and utilization of woodland and savanna vegetation. South African Journal of Wildlife Research 6: 1-32.

Westoby M. 1978. What are the biological bases of varied diets? The American Naturalist 112: 627-631.

Received 16 November 1998, accepted 15 December 1999. 